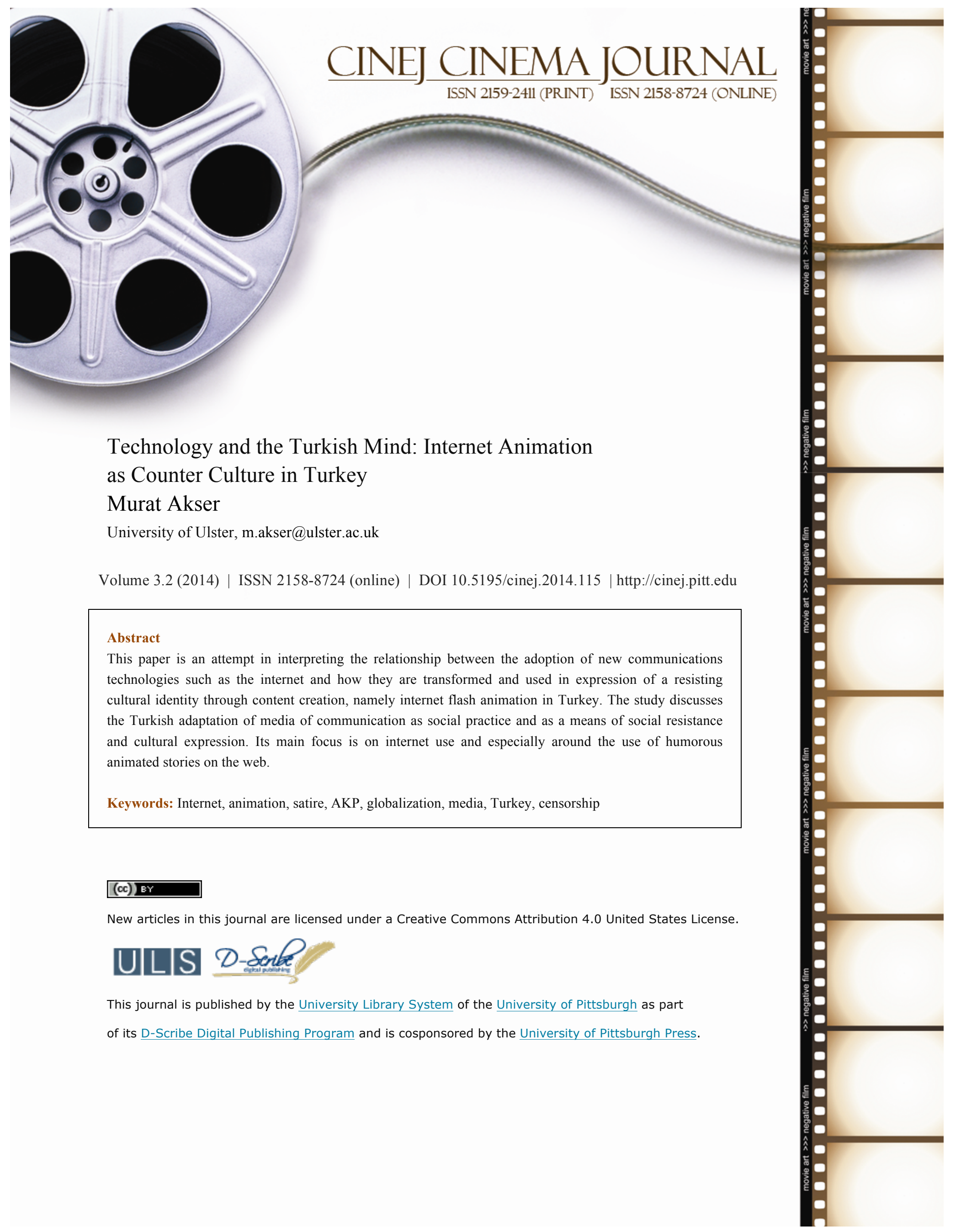




\section{Technology and the Turkish Mind: Internet Animation as Counter Culture in Turkey}

\section{Murat Akser}

It has been 18 years since internet was first introduced in Turkey on a mass level. Since 1995 the proliferation of websites and internet content multiplied by Turkish users both in and out of the country. Although there have been attempts by the Turkish government to limit the streaming of anti-government videos by banning YouTube and twitter, the persistence of the users helped them overcome such anti-media tactics (Akser and Baybars-Hawks 2012). In this article I will attempt to do a historical archeology of internet media. The user generated content on the internet is volatile in Turkey as it tends to disappear as their creators neglect to keep their websites operational or the content gets deleted due to change in service providers" change in management and policies (or sometimes they simply go bankrupt and shut down the service. Since the coming of AKP into power in 2002 there has been steady increase in antigovernment media. Social media such as YouTube, twitter and Facebook are all newcomers in this game as they have been operational for Turkish users only after 2007. There are government sponsored AK-Trolls who counter act against such critical discourses. There are Marxists hackers like REDHACK who are vocal against government policies (Akser 2015). The use of twitter and streaming technologies during Gezi Park protests in Istanbul in June 2013 proved that there are new methods of resistance against government totalitarianism using the internet. Before all that, in the 1990s when there have been only websites and material produced tended to be more critical. In the uncensored world of Turkish internet of the 1990s there were the flash animation heroes of the internet as counter culture discourse producers. 
These people created material that is critical of traditional discourse in Turkish society. The position of religion and secularism tends to produce conflict within Turkish society. The internet savvy youth of the 1990s produced material that was offensive in its time, mocking religious Islamic values. In time the producers of such material went on to produce mainstream material on television. An example is grafi2000 team who produced the below discussed animation Sayko Matrix now produces daily episodes of Koca Kafalar on Kanal D. They became mainstream by producing diluted critique of politics and society. Their alternatives are no better. The next generation producers of satire in Turkey like Bates Motel Pro team produce funny material, parodic of other media but not critical of discourses that crosscut Turkish society. The sample flash animated videos in this study reveal a time in Turkish internet that was vibrant and critical. By looking at the past of the internet this article hopes that similar critical stance will be taken in the future of the Turkish online media.

\section{THEORETICAL BACKGROUND}

The Technologies of communication are invented, western-European and North American countries define their parameters and policies. Such technologies of communication are result of an invention process described in detail by Brian Winston in his Media Technology and Society. When there is technological capability, a supervening social necessity and capitalist value, these inventions are adopted. The inventor holds a patent and makes money out of this deal. Such examples are Edison, Bell and Bill Gates who ruthlessly stole their rivals' ideas and dominated the market for decades. Yet non-western countries (i.e.. the rest of the world) do not posses this technology until they want to adopt it either through patent adoption and paying royalties or by creating hybrid technologies. The social-cultural nature of this western-based 
communication technology at first is not capable of expressing the histories and cultures of the adapting society. In time this new technology can be used in creative ways that were never conceived by their original western inventors. Potentially this new communications technology can give a voice to masses (as in Turkey) or it can be used to oppress them (as in Iraq) depending on the flexibility of the political regime and willingness of the elite in adapting this new technology. I intend to discuss the Turkish adaptation of media of communication as social practice and as a means of social resistance and cultural expression. My main focus will be on internet use and especially around the use of humorous animated stories on the web.

Communications technologies have an impact on human lice on both social and physical spheres. For example cell phones define whom we talk to, where and when. The users of cell phones can be parents who want to get hold of their teenage children, lovers who want to talk to each other all the time, businessmen who constantly try to get hold of their businesses. Television defines our space in living rooms and our daily schedules are arranged so that we can watch soap operas easily. Internet can be used to chat with new people, to find a spouse, to create animation that makes a critique of the effects of modernization on an eastern society. Like Marshall McLuhan said media of communication indeed has become an extension of human body/senses.

History and technology of communication and media in Ottoman Empire and later in Republic of Turkey was strictly controlled and closely monitored by the state until the 1990s. In the 1990s, radio broadcasting, local television, cell phone and the internet use gave a new voice to the social, the popular as well as subversive cultures (such as the phenomenal VJ, DJ Ayca Sen). I will briefly discuss these technologies and how they interact with the social space 
and culture but focus mainly on the uses of internet animation as the expression of the cultural and social formation process.

The North American-west European values of individualism and capitalism organized around principles of a bourgeois democracy are tightly integrated with how communication technologies are used socially and economically. The same principle applies to the societies that adapt such technologies but in a different way. The developing country makes a technology transfer. This is a transfer of mentality, social organization, material need adapted without giving much input in the creation of that technology. This essay sees this as an advantage. The borrowed technology gives birth to hybrid ways of socializing communication. The Turkish use of telephone, radio, television, wireless and cell technology is a case in point. Turkish people use these technologies to gap the distances (rural-urban), to talk more and more (in traffic, at home) and to express their daily lives and repressed cultural values. This is just a few examples of the happy mixture between orality and space-bound culture existing in a hybrid form in Turkish communication culture. Turkey has long been a hybrid society of communication media. Historically it has been an arena of a mixture of orthodox Byzantine and Turkish-Muslim culture, a mixed economy with a semi-democratic structure, an imposed Jacobin Republican modernization from above that is accepted by most of the population. The new communication technologies that emerged since mid-1980s added to this hybridity. Since the 1980 s the creation of a more liberal, market-oriented bourgeois democracy helped to establish a state-of-the-art communications infrastructure but it also allowed all dissent and critique of modernization to go to surface. Multiple channels of discourse came out and new platforms of dialogue opened as a result. For example no longer does the armed forces need to occupy state-owned TV and radio stations (as they did in 1960, 1971, 1980) to make a coup. 
Instead the army can use privately owned media to deliver its message covertly to warn the politicians and thus create the concept of "postmodern coups".

\section{Social Adoption of Communication Technologies: A Revised Model}

Using a Sausserian linguistic model, Brian Winston has a highly developed model for the adoption of a communications technology. In his model there is social sphere that dictates the supervening necessity of a media technology. His theory is more focused on the invention and adoption stages. Yet what happens after the adoption of such technology is also of equal importance. In my revised model I will include state apparatus as an agent and stages of use; introduction, fascination, exaggeration, subversion and regulation. Privatization can also be a part of the process if the media is introduced and immediately monopolized by the state.

In the Turkish case the state apparatus and its mechanism, government bureaucracy, were decisive in adapting new technologies of communication. In time the innovative use of such technology came from private individual bourgeois capital as well. One such case is Oguz Ozerdem who introduced 800, 900 service numbers and made millions of dollars as a monopoly. He later invested this money to create a private university that is particularly interested in media education (and employ all time big communist scholars-www.ibun.edu.tr). The state monopoly also secures its rights through legal means. For example in terms of telephone infrastructure, there is a monopoly of Turkish Telecom, which prevents the government from privatization because of an article in the constitution. Yet the legal loopholes allow for private individuals to make profit out of a creative use of this infrastructure such as internet service providers and cell phone companies. In the first section of the paper I want to 
discuss my revised model of use of communication media and the regulatory of role of the state. Then I will talk in detail about the subversive use of internet animation.

Telephone: Telephone came to Ottoman Empire as soon as it was invented. The introduction period took a long time because of the subversive potential of the new medium. Was suspected from the start. Abdulhamid II was an absolutist monarch trying to hold a multiethnic empire together. He had an extensive policing system to spy on any intellectual activity and telephone use would easily unbalance this. He also did not allow for the introduction of electricity, subway-public transportation and railroads to the empire easily. When telephone was introduced, it remained a luxury item for westernized bourgeois middle class families. The introduction phase went hand in hand with regulation phase for nearly a century. The liberalization of telephone use came with mid 1970s where every household, rich or poor, had a phone at least for emergency calls. With this came the fascination phase or use pleasure of new media. People who lived in long distances, family members whose sons went to Germany as immigrant workers had the opportunity to talk to each other on the phone. The fascination of this new media was so great that it bridged the gap between people and allowed for social cohesion, expression of ideas otherwise hard to confess to one's face (such marriage proposals, reconciling friends, bitter enemies making peace etc.). Exaggeration phase is when there is overuse of the media for a variety of reasons. Excessive talking on the phone for hours, calling each other day and night, connecting to internet 24 hours a day, downloading MPEG files forever occupying the phone lines are examples of overuse which may cost both the user and telephone companies. It is not uncommon to have 1000\$ phone bills in large cities and Turkish government changed its policy to let internet service providers to use the phone lines for free to connect their users to the internet. After realizing that second, third and even fourth party users 
took advantage of the free of charge approach of Turkish telephone before that decision. Subversion is the misuse of the new media. Such misuse can be exemplified as telephone psychos who call day and night to disturb people or play dirty jokes on people. One such case is the Ozdemir Affair. In the summer of 1989 four students from METU (Middle East Technical University-www.metu.edu.tr) wanted to play a joke on one their professors by calling him day and night, forcing him to use swear words (but they never swore on the phone). The students recorded these dialogues along with other recordings of practical jokes played on people of Ankara, distributing it in audiotape format for free on university campuses. Ozdemir tape became a legend for a decade now, also available on the internet and still finds its niche audience. The responsible people were never caught. Finally regulation is the defining and enforcing the legal use of new media. Government having initially introduced telephone service never knew that it would be misused that much. After each misuse the parliament passes new laws and penalties to prevent that or through Turk Telecom bylaws. The worst case of telephone misuse is wiretapping, listening to other people's phones. This could be via accident as well. For example $900 \mathrm{~Hz}$ wireless phones can have a similar signal in radio receivers and you can actually listen to people talking from your radio. Second, private individuals do it either for profit or some other purpose they set up special spyware equipment to eavesdrop. And finally police and secret services tap into phone lines thus seriously endangering the constitutional right to privacy of communication (public misuse of media).

Wireless Radio: Introduction of wireless technology is again state sponsored. The citizen band became famous in 1980s (fascination phase). After a while all radio frequencies were full of men looking for a female friend to chat (exaggeration phase). $\mathrm{CB}$ is still used for police 
purposes mostly, by film crews and pizza delivery companies. Yet the use of the wireless technology set some of the parameters for mobile phone.

Radio Broadcasting: The introduction of radio broadcasting goes back to 1930 s during Kemalist single-party, revolutionary, Jacobin era. During that time radio was used in fascist German and Italian regimes to reach the masses. This potential to inform and direct people was attractive to Kemalist revolutionary guard. The control of radio was very important in 1960 when the armed forces took over the government after a coup. The flat and strong voice of Colonel Alparslan Turkes, one of the leaders of the coup, announcing the coup from radio broadcasting still echoes in people's memories. The use of this media remained under strict government control until the 1980s. Then in 1986 TRT FM was introduced and new stereo high frequency sound attracted young people to their portable radio sets. The fascination period came when people could call the stations and ask for song on live on air. They began to chat with DJs and dedicate songs to their loved ones. With the explosion of private radio stations around 1991 the exaggeration phase began. Every city, every district, every town, every village, every university, even each government ministry had their own radio stations. To operate a radio station one only needed a PC, a 10.000US\$ radio broadcasting card \& software on it and a connection to an antenna. Thus everyone in Turkey have had their 15 minutes of fame. Radios never stopped commenting on any subject. It was as if Pandora's box had been opened. This attracted the attention of government and they had a court order to ban the private stations from broadcasting until a new regulation is in place. Already integrated to big private bourgeois capital, the radio stations launched a big campaign and called for a legalizing radios with a slogan: "I Want My radio back" asking everyone to wear a white ribbon to show their support to the radio. In early 1992 the government came up with a new entity: RTUK, an 
acronym for Radio Television Regulatory Board that works along the lines of FCC or CRTC. Since then radios are further corporatized and started broadcasting on the web as well. (Famous Ramona case). There a few media moguls such as Dogan Media Group that have control over production of newspapers, radios, cell companies, TV broadcasting and internet services.

TV Broadcasting: Television came to Turkey as early as 1952. Istanbul Technical University was interested in technology and had a local broadcast in operation until 1967. Between 1967-72 more and more area was serviced and more TV sets were brought. Yet this service remained a luxury service for a privileged few to enjoy. Significant changes happened after Turkey's second military intervention. The new interim military-backed technocratic government made investment to create nationwide television links between 1971-73. When return to democratic system happened in 1974, Turkish Radio and Television Broadcasting Corporation is created. TRT started nationwide 18 hour a day broadcasting. The fascination period following this development lasts long. In the early days single channel black and white television is an attraction is houses. Television set now fills the vacuum of the empty house space of old Turkish homes. Neighbors go visit friends with TV sets to watch Dallas. Later a second and color is introduced in 1986. By 1990 there are now five TRT channels for youth, international and national subjects, all color and broadcast worldwide through two Turk Telecom satellites (Turksat 1B and 1C). In 1990 suddenly the then president of the Republic, Turgut Ozal, breaks the TV monopoly law by encouraging his son, Ahmet Ozal, to establish the first private TV station in Turkey. By geo-political and historical luck Turkey's first private TV, InterStar, easily tops the ratings when it starts live broadcasting of Gulf War. Between 1990-97 10 nationwide private TV stations are established with hundreds of local ones. For the first time people are freed from the official republican Kemalist discourse of TRT and see CINEJ Cinema Journal: Technology and the Turkish Mind: Flash Animation as Counter Culture Volume 3.2 (2014) | ISSN 2158-8724 (online) ｜ DOI 10.5195/cinej.2014.115 | http://cinej.pitt.edu 
themselves live on TV, talking about everyday subjects from cooking to sex. This brings the exaggeration phase. For rating purposes private TV stations have no code of ethics and break every taboo. Explicit sex films appear on Show TV every night and sets an example to others who eagerly follow them to broadcast sex and violence in prime time. Masochism, sexual deviance, rape, torture, blood and guts become everyday news shown graphically shown on TV. People freely swear on TV, spit to each other faces, beat each other live for money in game shows. With the establishment of RTUK, the channels delevop ethical standards and this subversive potential is channels towards pay per view digital (scramble) channels. Now Digiturk and Star Digital offer pieces of 500 channel universe for people willing to pay for it.

Cell Phone: The first cell phone appeared in 1993 in Turkey. These phone were big, heavy, required charging often. Soon Motorola, Ericsson, Nokia and Sony came with their fancy cell phones and millions of people began using them. The operation of cell phones was immediately privatized and two major companies became oligopolist service providers (Turkcell and Telsim). Then fascination period began. Everyone was talking on the phone, sending each other online messages. The social use of the cell phones was that they allowed for faster communication in big cities like Istanbul where traffic jam is a problem and where mothers can track their children, lovers can arrange meetings. The exaggeration followed when people began hunting for cell phones with better technology, a tinier model and a different color cell phone. People started changing their cell phones nearly every month, second hand cell phone market exploded. There are now hundreds of different types of colorful cell phone covers. Like the automobile before itself, cell phone became a symbol of status; the silver plated Nokia became an icon of this mentality. Phone bills soared as people started downloading different cell phone ring tunes from the internet (cell phones in Turkey can play 
love songs, Beethoven's 5th symphony, tangos, and Islamic call for prayer-ezan). A new regulatory board, the Telecommunications Authority was established still tries to break the monopoly of the two cell phone companies. Iridium, second generation digital phones are also in use along with GPS services.

So far my analysis tried to show that introduction and regulation of media of communication is dependent on state-government power. The fascination period is always followed by an exaggeration phase potentially subversive us of the media by individuals. Second point is that historical, political and economic conditions determine the introduction of a media. As turkey' got richer and its income per capita increased to 5000\$ the introduction and usership rose. Third the arrival of each new media technology got faster than the previous technology. It took less time to adapt cell phones than adapting television. Internet came at the same time with industrial world powers.

\section{Internet Animation: Clash of Identities and Youth Culture in Turkey}

Finally the Internet is the latest media in Turkish society. There are now 20 million users from all ages but mostly between ages 15-25. Internet first arrived as BBS service in 1993. In 1995 world wide web became available through browsers such as Netscape Navigator and Internet Explorer. Initially internet was available in universities for student and faculty use. After 1996 the Telecommunications Authority commissioned the establishment of a permanent internet backbone by a triad: METU (domain name registration), Sprint (global links) and Satko (satellite operations). Later METU became the sole institution to deal with internet management. Soon e-mail use and visiting university websites gave way to online chat and games. In the fascination period everyone enjoyed the web ordering books through amazon,

CINEJ Cinema Journal: Technology and the Turkish Mind: Flash Animation as Counter Culture

Volume 3.2 (2014) | ISSN 2158-8724 (online) | DOI 10.5195/cinej.2014.115 | http://cinej.pitt.edu 
sending e-cards to loved ones. Later came exaggeration; people started cracking passwords and sending hate mails, download porn and expose their bodies for money through webcam. Losing sleep and malnutrition over excessive chat became commonplace among youth. A proposed internet regulation will is now forwarded as a bill $n$ Turkish parliament that gives powers to RTUK over the internet. With this regulation RTUK will have the authority to shut down websites whose content is politically and socially disturbing such as ethnic terrorist and separatist propaganda, child porn, The law also forbids smoking in internet cafes. Turkish internet users are mostly young people. It is affordable to have either fast cable or a dial up connection from home for $10 \$$ a month. Both men and women have equal access to the internet. Universities give free internet access, e-mail and SLIP accounts to all faculty and students. Turk Telecom has a flat cheaper ratio for internet dial-up connections.

Such was the entrance of internet to social life in Turkey. In this second part of the paper I will be discussing the latest novelty in internet by Turkish people: flash animation with humorous subjects. This particular use of a media of mass communication is far from reconciliatory and dialogue-based. One side of the rhetoric ideology creates its other and mocks it whereas the other cannot reply (fearing military response?). As is the overall argument of this essay, the use of media of communication is socially determined differing from society to society. Deborah Wheel puts it this way:

\footnotetext{
"Grand theories around global and local restructuring in the wake of the Information Age fail to see that each country has its own culture, style of government, norms and sanctions of behavior and gender attitudes, socioeconomic status structure, level of literacy and education, and historical experience. These factors help to shape what kinds of communicative acts are enabled by the Internet and which are discouraged (Wheeler 2001: 188).
} 
Urban westernized youth in Turkey uses the internet to have access to the world but also to experience a westernized life style. In that he uses the new tool to mock any potential threat to this life style such as conservative tendencies among some part of the society. In that humorous use of internet animation is the key to my discussion. Humor and satire have been known to excel in repressive and undemocratic societies. Turkish cartoons have been around since late 19th century. Akbaba in the 40s-50s, Girgir 60s and 70s reached the third largest circulation in the world after American Mad and Russian Krokodil magazines. Girgir's relentless tradition of social and political satire was marked in the types of charters it created. Prof. Zihni Sinir, En Kahraman Ridvan, Namcakoglu Cuneyid are heroes with absurd vulnerabilities experiencing bizarre events while they ridicule conservative, Islamic attitudes. This tradition was carried to Leman since the 1990s. Leman was launched in the tumultuous 1990s when there was a regional civil was in southeastern Turkey, disappearances of political activists and journalists were common as well as assassinations. Political right, especially oil money backed Islamic extremists were on the rise and money and free riding capitalism became a religion. Cartoons became political and more daring. The artists who drew them became legends. For example Selcuk Erdem's cartoons are widely circulated on the internet. Leman's humorous yet political stance and especially Erdem's cartoon style had significant impact on internet animation in Turkey. Basic themes of this animation follow this cartoon tradition.

Cultural theorist like Norton claim that the components of identity of a person can go up to ten items. Among the most common ones are place (of birth, raising), religion, ethnicity, class, nationality. In the Turkish flash animation pieces on the web we come across with a clash

CINEJ Cinema Journal: Technology and the Turkish Mind: Flash Animation as Counter Culture

Volume 3.2 (2014) | ISSN 2158-8724 (online) | DOI 10.5195/cinej.2014.115 | http://cinej.pitt.edu 
of identities. The creators of these animations define an other, someone ugly, deeply religious, rural. The society is portrayed as divided between choices in identity, of place, of ethnicity, of religious belief and of class differences as rural vs. urban, secular vs Islamic, western vs conservative. The creators of these animations have an urban, secular, westernized attitude that parodies the Islamic, traditional, community based people and create archetypes to mock them.

In an article on web Christopher Smit refers to American freak shows when he tires to explain the fascination with the web. The freak is the other, the distorted, silent caricature of a human being. The fascination of seeing this other can be a two-way relationship. The viewer may not be aware of the creator of the images, and in a moment of self-reflection he/she may experience these images acting as a catalyst for self-definition. The other serves both as a reflection mechanism of the viewer's fears and yet at the same time help him to define his identity. Smit also adds that "however fascination often carries with it a dark tone, an element of shame, something that historical memory wishes to forget" (Smit 2000: 130-136).

Starting from Smit's view we could claim that for the secular, westernized intellectual the characterization of its other is a Muslim, rural, communal person. Seeing this other as disgusting, absurd and ridiculed creates a one way fascination for its viewer. The other is a caricature to be ashamed of, a human being one wants to avoid associating with, a distorted and deformed man. There are three main archetypes of internet animation I will mention: Imam and Hoca types, i.e. rural men of religion living in the big city; degenerated urban youth, such as Sayko Kemal (Kemal the Psycho); and rural immigrants in the big city like Noel Dayi, Bekci Dayi (The night watchman). We will now go into detailed discussion of these animations. 


\section{IMAM and SAYKO KEMAL: THE FEAR OF RELIGIOUS VIOLANCE}

Kemalist ideology (as it is defined by the founding fathers of the Turkish Republic in 1923) is definitely anti-religious in its core. Its definition of secularism actually excludes all aspects of religion from civil life. The Turkish state takes sides and physically bars expression of religion, which it considers as threatening to the regime. Especially after the successes of Iranian revolution, the military guard acts like a Sword of Democles over the politicians' heads. The one and only premiership of a religious party leader lasted a yea until the military made a postmodern coup using television to politely ask the PM to step down in July 1997. These developments coincide with the coming of internet to Turkey. The young web designers come from middle class bourgeois urban background with a westernized education. Most of them can speak English and other European languages. They aspire to lives of Europeans and despise anything eastern. The food, music and language of Arabs are among the most hated items (the Arabic language based on consonants from the throat is ridiculed a lot in imam animations). The religious values of the rural people are also the target of these young web creators. Such web geniuses are Berk Tokay, Onur Kek, Bora Kekik, Onur Alptekin, Murat Akar and Resul Ertas. Berk and Onur are the most prolific and original creators. Their Imam and Sayko characters are notoriously grotesque and disgusting. Imam and Sayko have several adventures:

Imam vs Pokeman: Imam is introduced as a 63-year-old bigot from Konya, the most conservative city in Turkey, known to be the city of Rumi the poet. His insignia are takunya (sandals) and tesbih (beads). Imam's first encounter is with Pokeman. As imam walk on his way to mosque he encounters Pokeman, the Japanese animation character. Imam is infuriated and accuses Pokeman of poisoning young people's heads. After much insult Pokeman calls for

CINEJ Cinema Journal: Technology and the Turkish Mind: Flash Animation as Counter Culture

Volume 3.2 (2014) | ISSN 2158-8724 (online) | DOI 10.5195/cinej.2014.115 | http://cinej.pitt.edu 
help and his sidekick, a bizarre looking creature, Pikachu, comes for help. Imam destroys Pikachu with a huge weapon and leaves a weeping Pokeman behind, he gets inside the mosque.
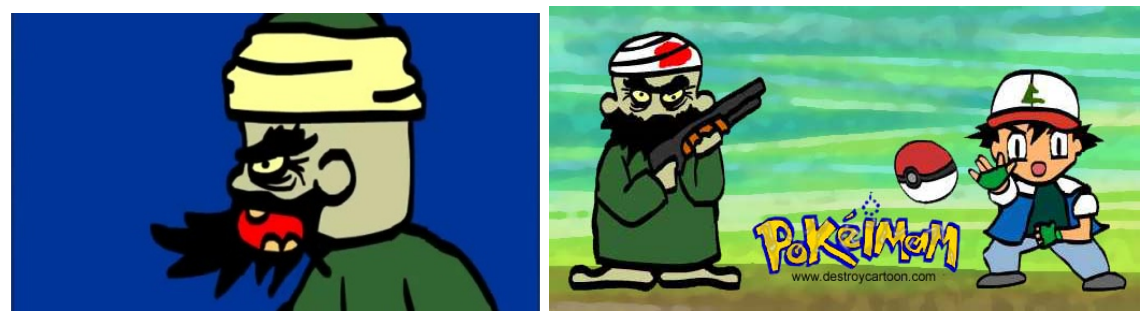

Imam presented as a swearing and violent figure in Pokeimam

This is an example of Kemalist discourse on religious intolerance. Imam, the ultimate representation of Islam is represented as an intolerant pervert. On his way to mosque he looks at young women's legs in mini skirts and accuses them of being sluts, a sign of his/Islam's intolerance towards women's freedom in civil life. The animation has another level of critique as well. In Islam any kind of pictorial representation is forbidden. Art is sees as trying to recreate a human thus blasphemy of imitating God (sikr). Thus reproduction of detailed images are forbidden (such as Japanese (pagan) animation that is popular worldwide). There are actually Pokeman worshippers in Turkey and children love to watch the show, buying their toys en masse. Through imam's persona, the creators of this animation play a dual role. Not only do they use a villain, imam, to make a critique of Japanimation as a mindless tool (as lovers of computer animation they cannot easily say it aloud themselves), but they also find an opportunity to attack religion by depicting religious and conservative people as violent and inclined towards violence. Imam's voice is coarse and his shriek deafening. When he gets upset white saliva comes out of his mouth as if he is a dog with rabies. Thus imam is the ultimate freak, the other on whom urban Kemalist youth wants to reflect their identity.

Imam vs Sayko Kemal: Imam's next encounter is with Sayko Kemal (Kemal the Psycho). Kemal is introduced as a 22-year-old urban boy. He has a goat like red beard, a sign of 
westernized look. He looks like a skinhead, a Satan worshipper or a rock metal fan. He definitely has an ultra westernized urban style, which is very much apart from everyday realities of ordinary people. Kemal is disturbed one night when Imam calls for prayer at five am. Looking outside his window, Kemal swears at Imam. They both exchange swear words and finally Imam retaliates with a weapon. As Sayko Kemal is destroyed so is Imam, falling out of minaret and hitting his head on the pavement. It is important to note the subtleties of appearance and verbal expression. Imam uses Koranic words in his verbal insult, words like iblis (demon), ecnebi yaratik (foreign alien), and putperest (pagan worshipper) when he is referring to Sayko. This is an example of clashing identities and worldviews. Since Turkey is a secular country no one actually has to go to mosque for a prayer (unlike Arab countries). He wants to sleep and have fun. This is disturbed by imam and he is free to swear. Yet one can never take it to extremes because Islam actually commands the destruction of blasphemers immediately. So literally the imam blows Sayko. This is a clear reference to Sivas events where during a communist gathering of atheist intellectuals in a small Anatolian city in 1993, the local major gathered a group that eventually burnt down the hotel. Several intellectuals died. Aziz Nesin survived. it is claimed that his call for getting rid of Islam all together ignited the protests. On the other side of the story there is this dual critique again. Secularism does not mean swearing at religion and Sayko because he is so intolerant and disrespectful towards other people's beliefs, he is punished in the end. 


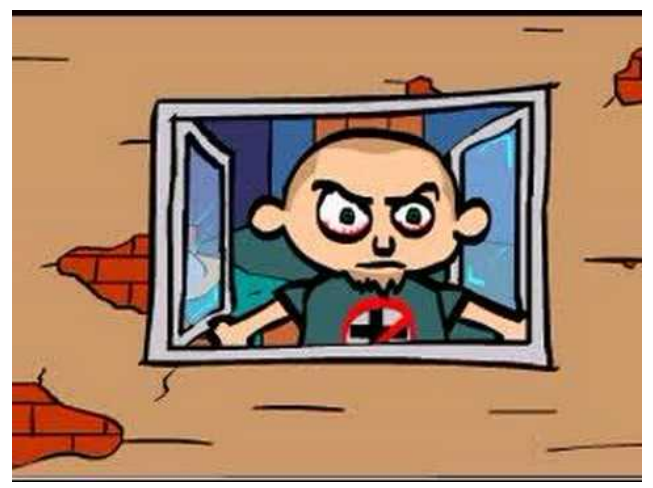

Kemal yells at the imam for reciting call to prayer too loud

Similar imam-like figures appear in other animation such as the Oflu Hoca figure created by Onur Alptekin. Oflu Hoca is a preacher at a local mosque every Friday in Of, a town Black Sea region. Black Sea region is mostly populated by Laz people. Laz are ethnically different from other regions in that they came with the 4th crusade and settled in the region around 13th century. They speak a version of old Nordic German and French and some mixture of Georgian. Their Turkish accent is very heavy and because they earn their living fishing, there are jokes around their stupidity, which is attributed to eating fish all the time. After their conversion around mid 15 th century to Islam, Laz people became very conservative Muslims. Especially obsessed with male honor shaped around female sex. Laz people are heavily armed they are famous for vendettas. Oflu Hoca is obsessed with there topics: entertainment in general, newspapers and women on TV who dress freely. In a very serious preacher manner, Hoca explains fornication in his funny accent. This hoca also uses heavy Arabic words and swears mostly. So in addition to rural and Islamic other, the Kemalist discourse in the animations have an ethnic bias against minorities such as the Laz.

Sayko Matrix: Later on Kemal has other adventures of his own such as Sayko Matrix. This time Kemal is again disturbed in his sleep by his neighbors upstairs. When he goes up to talk to the neighbors, we see that they are even more marginal than Sayko. The men and a woman are 
dressed in hip hop and raggee attire dance to a strange beat. In a Matrix like adventure Sayko butchers them all. The critique her is once again on violence and extreme westernization.

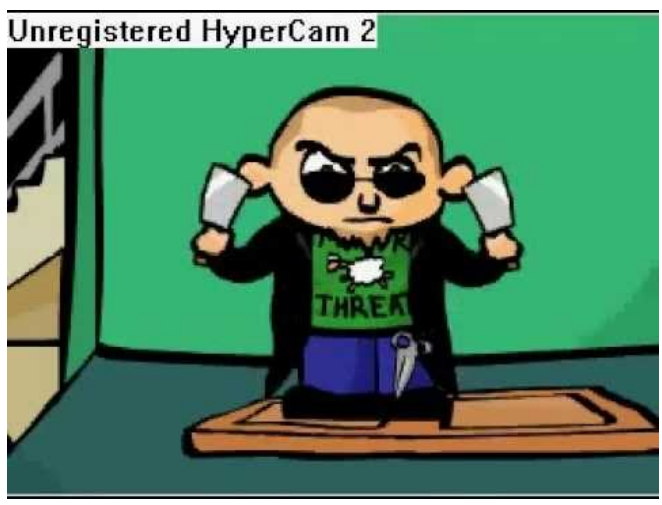

Kemal the Psycho protests the noise by the neighbors.

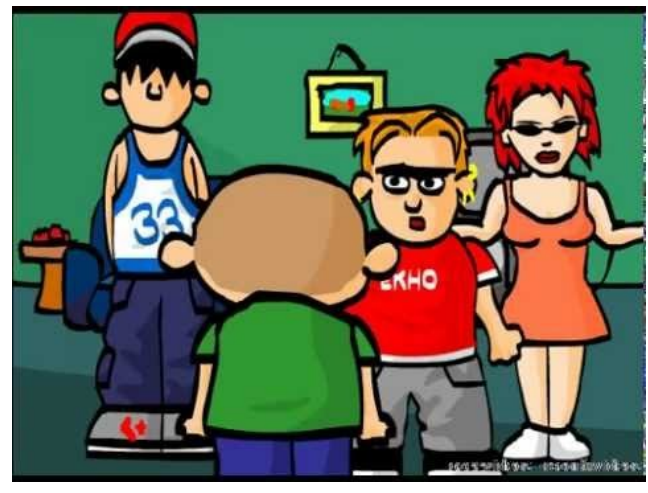

The neighbors do not care about Kemal

Sayko Goklerde (Psycho in the Skies) is another interesting animation. This time Sayko Kemal wants to parachute jump. He is first hit by a Turkish Airlines jet (a critique of incompetence by government operated enterprises) and then by an American missile (critique of unconditional cooperation with American military interest on Turkish soil). The animation is cut in between by a flash news episode on a Turkish TV channel presents the renegade American missile. The news reporter is a clown and plays with apples instead of reporting this grace accident. He says "we have just put our names to another first on television history" and in less than a second he quickly says: "US just sent a missile" and the news cast ends. Here TV journalism ethics criticized. The facial gestures of the clown resemble all three primetime newscasters of the biggest major TV stations in Turkey (Ali Kirca-ATV, Reha Muhtar-Show TV).

\section{MAGANDAS: NOEL DAYI AND BEKCI DAYI}


Maganda is a pejorative term for the rural immigrant in a big city. It is used to describe a man without manners, someone lacking polite and kind behavior. Magandas are referred to as rapists, thieves, dirty and ugly people. This urban way of describing the other finds its epitome in Noel Dayi, literally Turkish Santa Claus. Noel Dayi is a two-minute animation by Berk Tokay, a graphics design student at Bilkent University. Noel Dayi sings a Turkish version of Jingle Bells as we watch him trying to distribute toys to kids during Christmas. Yet Noel Dayi is very much Turkish. His attempts to imitated his western counterpart fail. Noel Dayi has a dirty beard instead of white and soft beard of Santa Claus. He likes to show his chest hair, his hat and clothes do not fit him. He drives a taxicab run by deers instead of a slate. He is actually assisted by a dancing deer throughout the animation. Noel Dayi tries to go into chimney but he cannot fit in. Instead he breaks into people houses from the front door and spits on their faces, an ugly green saliva. He brings electric utility instead of toys and kills children. He likes to show his animal side towards women as well.

In Noel Dayi 2, the amount of graphic violence increases. Noel Dayi is now a popular phenomena and urban kids idolize him wearing his T-shirt. A young boy sees Noel Dayi and wants him to reveal his identity. Noel Dayi himself refuses to reveal himself a few times. In the end Noel Dayi gets his upset, brings takes out a sword and cuts the boy into two parts. Now that the boy is split to two both parts of him go on talking and sing Noel Dayi's song in chorus. A confused Noel Dayi is this time encountered by a transvestite. Noel Dayi cannot understand if he is talking to a man or a woman. There are a lot of popular jokes around rural men who just arrive at the city, pick up a girl to have sex at night that turn out to have a male sex organ. It is important to note the sexuality and gender definitions of Dayi is portrayed as a straight macho 
man who cannot understand the subtleties of urban sexual choices, such as drag queen and transvestites.

In Noel Dayi 3, urban children come to his throne one by one. This time Noel Dayi talks sweet to kids (in a Sener Sen accent). First a boy comes with a yellow-red toy car. He says his team wears yellow-blue (Fenerbahce Soccer Club) colors. He asks Noel Dayi to change the car. Noel Dayi slaps the boy three times breaking his teeth and gives him a black eye. Now the boy now accepts the car as it is which means Noel Dayi is actually supporting the other team (Galatasaray ST). Next a young girl comes and complains that her doll has one arm only. Noel Dayi reaches for his word and severs one arm of the girl. Finally an antisocial boy comes and confronts Noel Dayi. As a reaction Noel Dayi spits on the boy. This time supporting a soccer club, identifying with it enough to kill someone is the major focus of critique. Noel Dayi does not hesitate to harm the child because he does not accept to celebrate his team's colors.

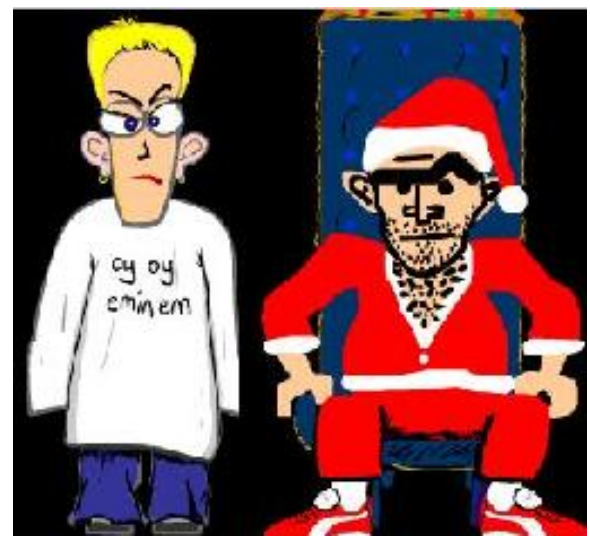

Noel Dayi confronts Eminem

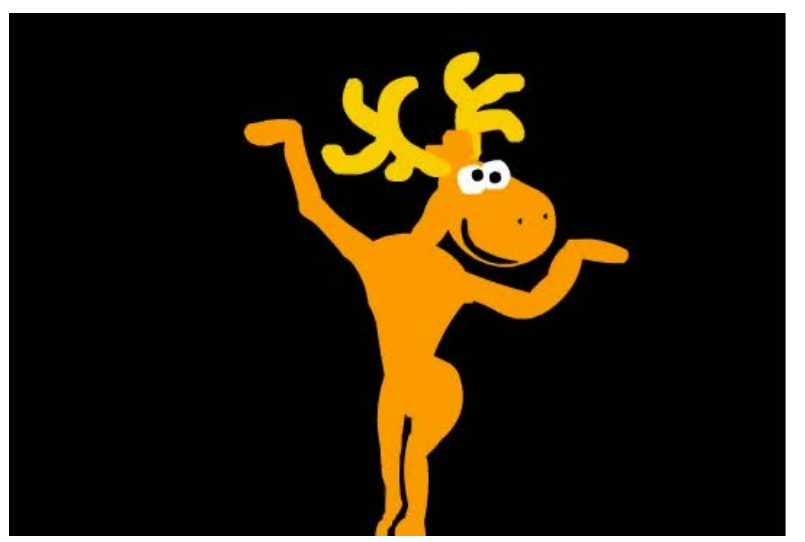

Noel Dayi’s deer walks and talks

Bekci Dayi: Another interesting character is Bekci Dayi, the night watchman. Dayi is watching his favorite TV show, Iboshow presented by Ibrahim Tatlises, an illiterate Kurdish ex-construction worker who turns out to be a popular singer. Suddenly roller skating kids come near the bank he is guarding and make noise. The kids break windows and damage property 
near the bank. Dayi goes out to warn them but one of the kids swear at him. Thus he beats the kids. When he comes back he has missed his favorite show.

Dayi's appearance is a typical Kurdish look. He has a dark hairy face complete with huge eyebrows. The kids look very urban and even one of them is blonde and has a very fair skin, an indication of mixed middle-European immigrant blood (Kemal Ataturk was a Macedonian blonde). Dayi refers to blonde kid as sari ciyan (blonde bastard), and brown one as yamyam (cannibal-pejorative for Africans). Thus multi-layered ethnic discourses are hidden here. From Dayi's perspective the kids aren't only children trying to have some fun. Dayi's anger comes out of ethic and class differences (he is Kurdish, only a night watchmen, these kids could be children of bank managers whom he constantly refers to as the S.O.B. Bank Manager). Not able to cope with these differences peacefully Dayi punishes the kids thus their way of life. Yet he cannot win eventually as one of the beaten kids are give him the finger back from the surveillance monitor.

There more animations around violence and intolerance of rural immigrant in the city like Sofor, the bus driver. Our hero, a young urban man complete with his piercing and a blue beard tries to get on a bus for free. He looks around himself and all he sees is rural people dirtying his city, pissing on the wall etc. He gets on a bus but does not have enough fare. The driver insults him, forces him to get off indicating that he is soft (gay) and would pay as a sexual exchange if he wants. Once again the driver is depicted as the rural ugly other. He is homophobic but at the same by delighted by the possibility of having sex with such a weird looking young man. 


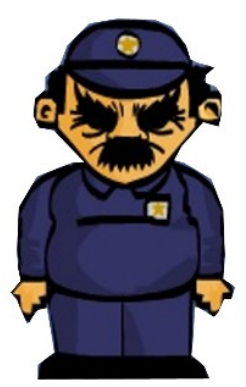

Bekci Dayi protects the grounds

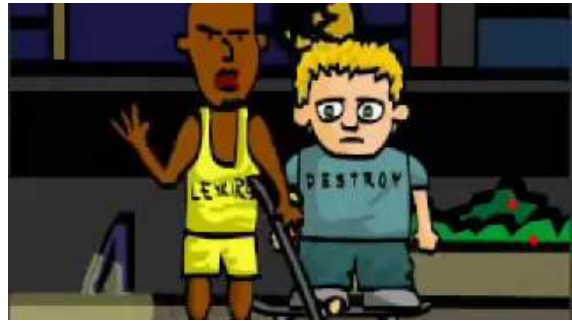

Street kids who cannot get their ball back

\section{CONCLUSION}

In this paper I tried to show that uses of new media differ from culture to culture. Transfer of media technology and its later use deserves further research. In a developed model of adaptation-use of media technology in a non-inventing country such as Turkey, I outlined several stages of use such as introduction, fascination, exaggeration and regulation. Especially exaggeration phase allows for misuse and subversive potential of new media comes out. One such example is Internet flash animation in Turkey. Internet's function as expressing one's identity comes out with these animations as the urban youth both uses a dominant identity discourse and attacks its other, rural, Islamic and conservative people in Turkey.

Web links:

Is Bankasi

http://www.erenet.net/animasyon.php?op=izle\&id=281\&isim=Is_Bankasi

By Onur Alptekin

Oflu Hoca

http://www.erenet.net/animasyon.php?op=izle\&id=104

By Murat Akar

Sofor (Bus Driver)

https://www.youtube.com/watch?v=BqGh3AR5SoE

Mezarci Mesih 
http://www.eskisehirliyiz.biz/eglence/flash index.asp?sec=3\&otelid=503\&bolgeid=20

Osama vs Bush in 2070

http://www.erenet.net/animasyon.php?op=izle\&id=165\&isim=Usame_Bin_Laden_2001

Main Comedy Sites:

http://grafi2000productions.com/diziler/

\section{REFERENCES}

Akser, Murat and Baybars-Hawks, Banu (2012) Media and Democracy in Turkey: Towards a Model of Neoliberal Media Autocracy. Middle East Journal of Culture and Communication, 5. pp. 302-321.

Akser, Murat. 'The Revolution will be Hacktivated: Turkish Marxist Hacker Groups' in Banu Akdenizli ed. Digital Transformations: Exploring Current Perspectives in Communication Studies. Lanham, MD: Lexington Books, 2015.

Derman, Deniz. "Information Technologies: The Turkish Case" in Deniz Derman and John Lotherington eds. Communications Revolution, Ankara: Med-Campus Project, 1996.

Ess, Charles and Fay Sudweeks eds. Culture, Technology, Communication: Towards an Intercultural Global Village, Albany: State University of New York Press, 2001.

Gauntlett, David ed. Web.Studies $2^{\text {nd }}$ edition, London: Arnold, 2004.

Kandiyoti, Deniz and Ayse Saktanber eds. Fragments of Culture: The Everyday of Modern Turkey, London: IB Tauris, 2002.

Hugh Mackay and Tim O'Sullivan eds. The Media Reader: Continuity and Transformation, Sage, 1999.

Kaymas, Serhat Ahmet. Media Policy Paradigm Shift in Turkey: Rethinking Neo-

Authoritarian Media Systems in the Age of Neo Liberalism. Acta Universitatis Danubius. Communicatio, Vol 5, No 1 (2011).

Keyder, Çağlar. "The Dilemma of Cultural Identity on the Margin of Europe" 16.1, Review, (1993), 19-33.

Koloğlu, Orhan (2004). The Printing Press and Journalism in the Ottoman State. Boğaziçi Journal 18(1-2): 27-33.

Mardin, Serif. Religion and Social Change, Albany: State University of New York Press, 1989. 
Norton,William. Cultural Geography: Themes, Concepts, Analyses, Don Mills, ON: Oxford University Press, 2000.

Öncü, Ayse. (2004). The interaction of media and politics: The remaking of the Turkish media industry in the 1990s. Boğaziçi Journal, 18(1-2), 11-26.

Öncü, Ayse. (2012) Television and media. In: Heper, Metin and Sayar1, Sabri, (eds.) The Routledge Handbook of Modern Turkey. Routledge, London.

Robins, Kevin and Frank Webster. Times of the Technoculture: From the Information Society to the Virtual Life, London: Routledge, 1999.

Robins, Kevin. "Interrupting Identities: Turkey/Europe” in Stuart Hall and Paul de Gay eds. Questions of Cultural Identity, London: Sage, 1996.

Robins, Kevin and Asu Aksoy. "Peripheral Vision: Cultural Industries and Cultural Identities in Turkey", 29, Environment and Planning A, (1997), 1937-1952.

Ross, Karen, Deniz Derman and Nevana Dakovic eds. Mediated Identities, Istanbul: Istanbul Bilgi University Press, 2001.

Smit, Christopher R. "Fascination: The Modern Allure of the Internet" in Gauntlett ed.

Turkan, I. (2012). Democratisation and New Media Dilemmas: a Case Study of Press Freedom in Turkey. Irish Studies in International Affairs, 23(1), 23-35.

Turkle, Sherry. Life on the Screen: Identity on the Age of the Internet, New York: Simon and Schuster, 1995.

Webster, Frank. Theories of the Information Society $4^{\text {th }}$ edition, London: Routledge, 2014.

Wheeler, Deborah. "New technologies, Old Cultures: A Look at Women, Gender and the Internet in Kuwait" in Ess ed.

Winston, Brian. Media Technology and Society A History: From the Telegraph to the Internet, London: Routledge, 1998. 